B 106

\title{
エクセルによる数値解析プロセスの可視化
} 一不等間隔格子による定常解析一

\author{
富村 寿夫 ${ }^{\circ}$ (熊本大学)，小系 康志 (熊本大学)，鳥居 修一（熊本大学） \\ 平澤 茂樹 (神戸大学)，奥山 正明 (山形大学)
}

\section{Visualization of Numerical Analysis Process by Excel Proceedings - Steady-State Analysis Using a Nonuniform Grid -}

Toshio Tomimura, Yasushi KoIto, Shuichi Torir

Shigeki HIRASAWA, and Masaaki OKUYAMA

\begin{abstract}
In the numerical analysis using Excel, each cell can be regarded as a nodal point, and calculations are performed by using equations written in those cells without making any programs. Furthermore, a concrete image or a computation domain corresponding to the physical model can be drawn directly on the spreadsheet, and by doing such classification as coloring boundary and interior cells, writing and debugging are visually conducted with ease. Moreover, the calculated results shown in the computational domain are immediately visualized using the Chart Wizard. In the present study, a method of numerical analysis, which is essential to perform practical calculations, has been shown for one-dimensional steady-state heat conduction problems.
\end{abstract}

Keywords : Excel, Spreadsheet, Numerical analysis, Nonuniform grid

\section{1. 粕輔}

エクセル解析では，ワークシート上のセルを格子点と 見做し，そのセルに差分化した式を埋め込むことで，プ ログラムを組をことなく，簡単に反復計算を実行するこ とができる。また，セルの色分けやワークシート分析の 機能を有効に組み合わせることで，式の書き込みやデ バッグを視覚的に行うことができる。さらに, 解析結果 は，付属のグラフウィザートを使用することにより，直 ちに可視化することができる。

最近，森下 ${ }^{11}$, Holman ${ }^{2}$ また岩井ら 3)などにより，エ クセルのこのような簡便な表計算機能とグラフィック機

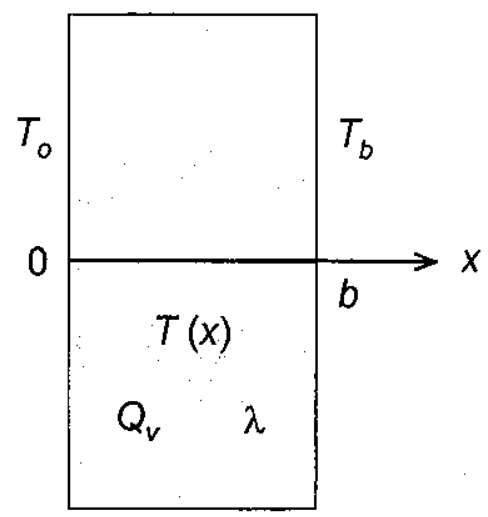

Fig. 1 Physical model for 1-D analysis.
能を利用した実用的な熱流体解析手法の開発や工学分野 におけす教育への応用が試みられている。

著者らは、既報 4)で、不等間陻格子の導入方法につい て、ふく射加熱をうける 1 次元平板系の非定常熱伀尊問 題を例とした検討結果を報告した。しかし、そこでは不 衫分割した空間座䬺 $x_{i}$ そのものではなく座標間の差 $\Delta x_{i}$ を導入したため、視覚的に若干わかり難い表示となった。

ここでは、実用的な数值解析を行う上で必要不可欠な、 より簡単な不等間隔格子の導入方法について、1 次元定 常熱伝導問題を例として検討した結果を報告する。

\section{2. 解析対象、基碟方程式および境界条件}

\section{1 解析対象}

Fig. 1 に示す上うに, 厚さ $b[\mathrm{~m}]$, 䱈伝導率入 [W/

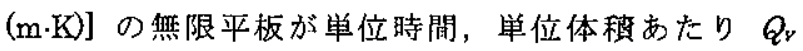
$\left[\mathrm{W} / \mathrm{m}^{3}\right]$ で発熱 $(>0)$ あるいは吸熱（<0）している場合 を考える. 平板の左面温度が $T_{0}\left[{ }^{\circ} \mathrm{C}\right]$, 右面温度が $T_{b}$ $\left[{ }^{\circ} \mathrm{C}\right]$ に保たれている場合の温度分布 $T=T(x)$ を差分法 により求める。

\section{2 基碐方程式および境界条件}

この場合の基礎式と境界条件は,

$$
\begin{gathered}
d^{2} T / d x^{2}+Q_{v} / \lambda=0 \\
x=0 \text { で } T=T_{o}, \quad x=b \text { で } T=T_{b}
\end{gathered}
$$




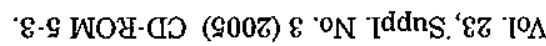

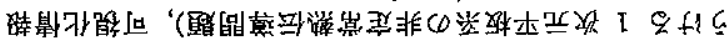

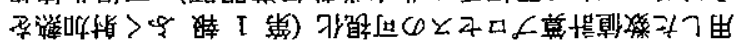

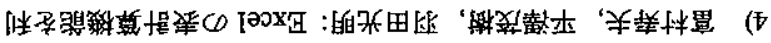

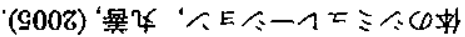

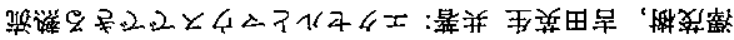

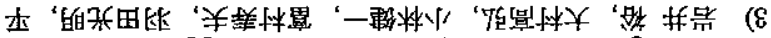

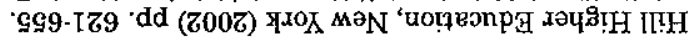

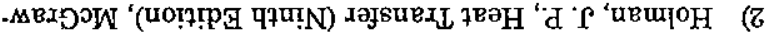

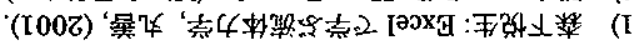

\section{程}

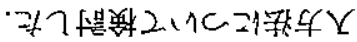

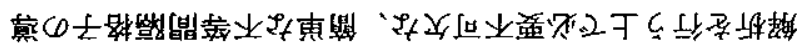

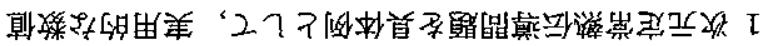

\section{㟟 踥 ‘}

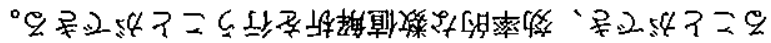

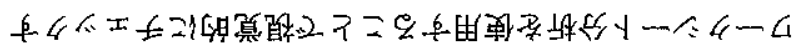

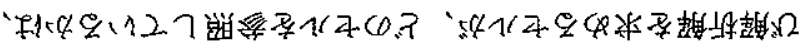

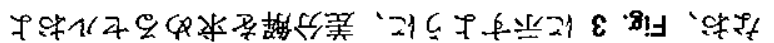

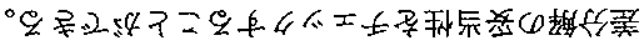

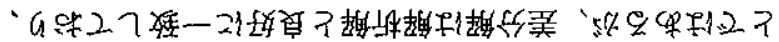

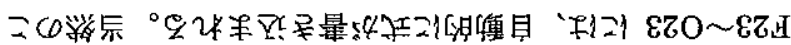

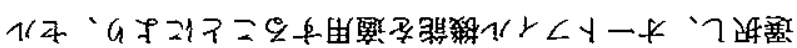

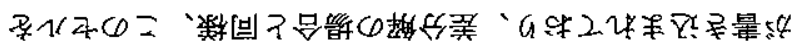
(L)

$9 \$ D \$+(\varepsilon \$ D \$ / L Z T) *(9 \$ D \$$

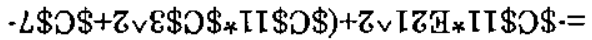

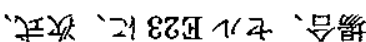

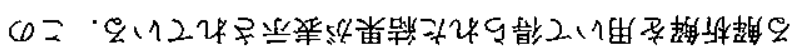

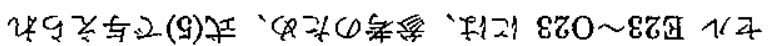

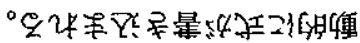

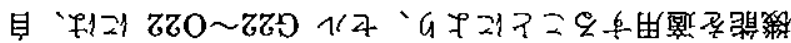

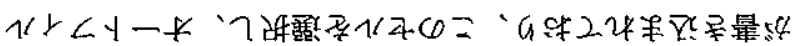

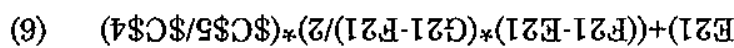

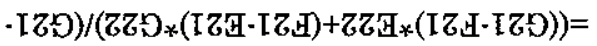

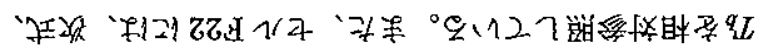

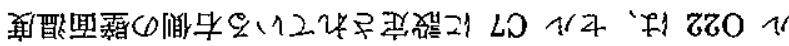

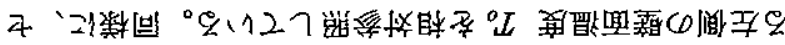

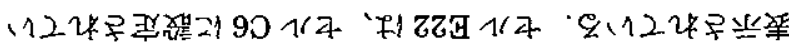

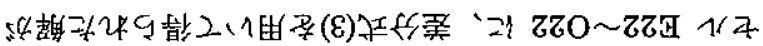

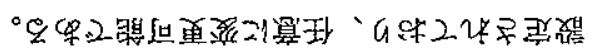

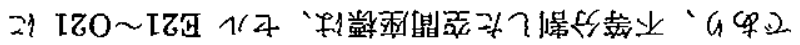

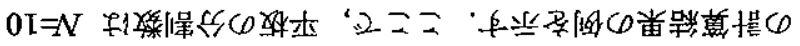

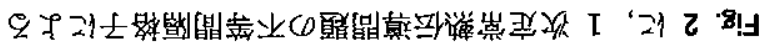

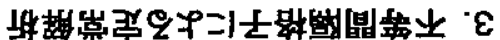

(9) ${ }^{o} L+(q / x)\left\{\left({ }^{o} L-{ }^{q} L+z /{ }^{2} q(\gamma / \wedge)\right\}+z / z^{\wedge} x\left(\gamma /{ }^{\wedge} \delta\right)-=L\right.$

${ }^{\circ} \mathrm{2}$ ४⿻一𠃋十

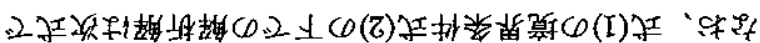

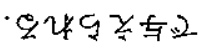

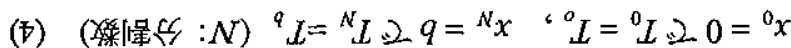

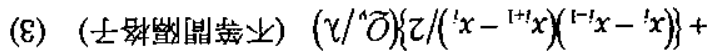

$$
\left({ }^{1-t} x-{ }^{1+t} x\right) /\left\{{ }^{1+t} \not\left({ }^{1-t} x-{ }^{t} x\right)+{ }^{1-t} l\left({ }^{t} x-{ }^{i+t} x\right)\right\}={ }^{t} L
$$

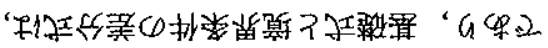

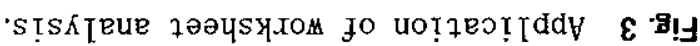

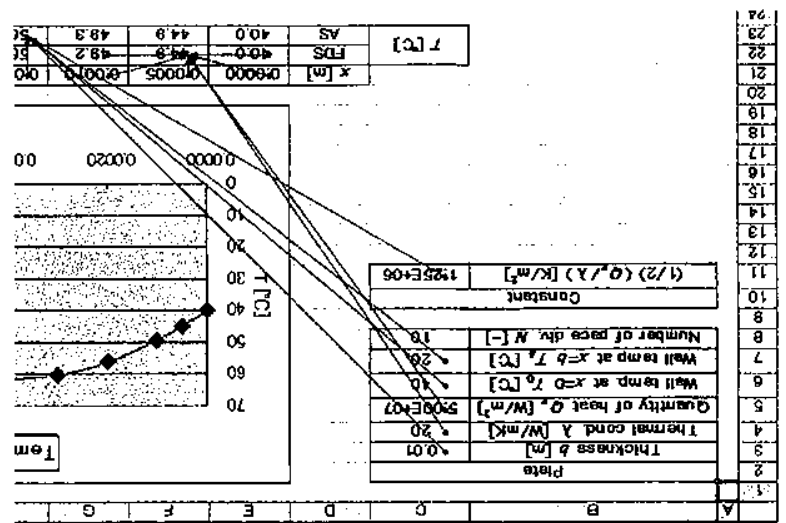

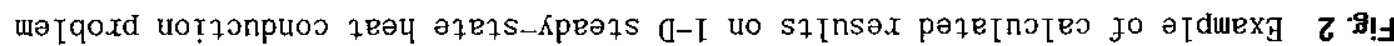

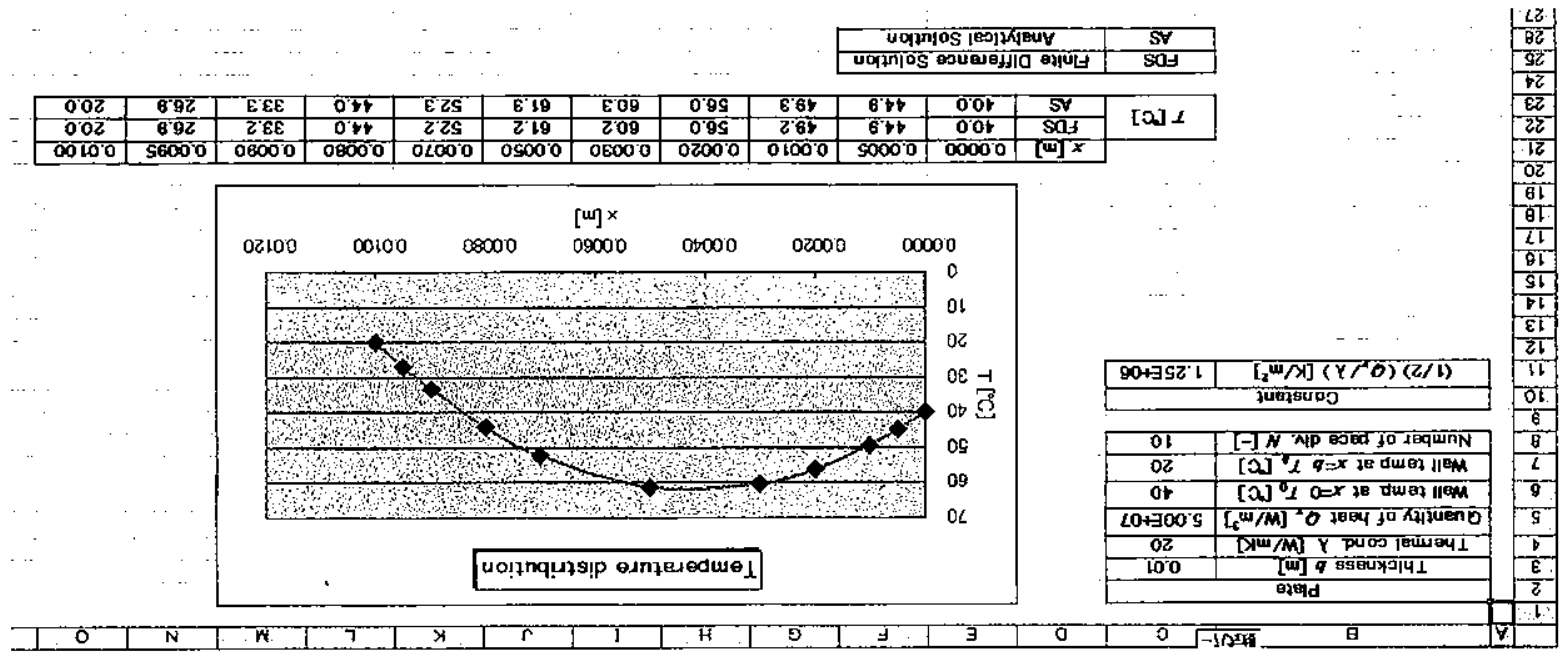

